\title{
MEMBACA 'KEBENARAN' NIETZSCHE
}

\author{
Yulius Tandyanto
}

\author{
| Graduate Student \\ STF Drijarkara \\ Jakarta, Indonesia
}

\begin{abstract}
:
Nietzsche's early work that gives wide exploration of the idea of truth is his unpublished essay entitled Wabrheit und Lüge in Ausermoralischen Sinne (1872). His controversial statement in this essay was "Truths are illusions", opening many interpretations among scholars in understanding his position on truth. Sarah Kofman argues that it is useless to speak about truth in Nietzsche's philosophy, for values are neither true nor false. Referring values to truth means forgetting to place oneself "beyond good and evil." Unlike Kofman, Maudemarie Clark separates sharply Nietzsche's critique of metaphysics and his denial of truth. Clark argues that Nietzsche rejects metaphysics and eventually overcomes it in his own work, but also that he ultimately affirms the existence of truths and therefore does not undermine his own theory when he claims truth for his own position. Clark's strategy in defending her theses tries to explain that there is a turning (Kehre) in Nietzsche's position. This article wants to offer an interpretation that Nietzsche does not make a new theory of truth in $W L$, but rather examines and constates truths that hold true. With his subtile and metaphoric style, Nietzsche might want to vivify the symbolic and figurative elements in language before the truth or reality that already escapes languages.
\end{abstract}

Keywords:

truths $\bullet$ values $\boldsymbol{\bullet}$ interpretation $\bullet$ falsification theses - metaphor $\bullet$ language

"Jadi, apa itu kebenaran [Wabrheit]? Sejumlah gerakan pasukan metafora, metonimi, dan antropomorfisme [Ein bewegliches Heer von Metaphern, Metonymien, Anthropomorphismen]; pendeknya, suatu total 
dari hubungan manusiawi yang kompleks, yang diperkuat, yang telah dialihkan [übertragen], dan diperindah secara puitis dan retoris sehingga setelah penggunaannya dalam jangka waktu yang panjang tampak bagi manusia sebagai hal yang tetap, kanonis, dan mengikat. Kebenarankebenaran adalah ilusi-ilusi yang telah seseorang lupakan sebagai ilusi-ilusi [die Wabrheiten sind Illusionen, von denen man vergessen hat]; mereka adalah metafora-metafora yang telah aus/usang [abgenutzt] dan telah kehilangan kekuatan inderawinya, [ibarat] koin-koin [Münzen] yang kehilangan tatahan ukirannya sehingga menjadi besi belaka [nun als Metall] dan bukan lagi koin."1

—Nietzsche, WL [KSA 1, 880-1]

\section{Introduksi}

Kutipan di atas yang berasal dari esai Nietzsche berjudul "Kebenaran dan Dusta dalam Pengertian Selain Moral" (Wabrbeit und Lüge im Aussermoralischen Sinne-selanjutnya disingkat WL) merupakan salah satu teks yang memperlihatkan posisi Nietzsche mengenai kebenaran. Berdasarkan teks itu pula muncul beragam tafsiran kreatif sekaligus polemik berkaitan dengan posisi Nietzsche terhadap kebenaran. Dalam tulisan ini saya menyuguhkan tafsiran Sarah Kofman dan Maudemarie Clark, khususnya penafsiran yang berkaitan dengan pernyataan Nietzsche bahwa "kebenaran adalah metafora" atau "kebenaran adalah ilusi".

Secara ringkas, Kofman akan menegaskan bahwa pembicaraan mengenai kebenaran tidak relevan dalam filsafat Nietzsche. Di sisi lain, Clark akan memperlihatkan bahwa pada akhirnya Nietzsche mengafirmasi keberadaan kebenaran, meskipun telah menolak kebenaran metafisis (ihwal-dalam-dirinya). Selain kedua tafsir tersebut, saya juga akan menawarkan sebuah posisi tafsir lain yang memperlihatkan bahwa Nietzsche mengafirmasi jenis kebenaran yang sudah selalu luput dari segala upaya manusia untuk menggapainya.

\section{Sarah Kofman}

Filsuf Prancis, Sarah Kofman (1934-94), mengembangkan gagasangagasannya dalam ranah yang sangat luas, seperti estetika, kritik sastra, sejarah filsafat dari pra-Sokratik hingga Derrida, psikonalisis Freudian, feminisme, tulisan otobiografi, maupun kritik seni dan film. Secara umum, 
Kofman lebih dikenal sebagai penafsir Freud, khususnya tafsiran feminis terhadap Freud (The Enigma of Woman: Woman in Freud's Texts). Namun, di tengah cakupan kajiannya yang luas, Kofman juga termasuk perempuan penafsir Nietzsche yang "otoritatif" setelah Elisabeth-Foster dan Lou Andreas-Salomé. Dalam esai berjudul "Kofman's Nietzsche" dalam buku Intepreting Nietzsche: Reception and Influence (London and New York: Continuum, 2011), Duncan Large dalam menyatakan:

"Di tengah kekayaan dan keragaman produktivitasnya, Kofman juga menjadikan dirinya sebagai perempuan penafsir yang otoritatif dan sangat berpengaruh mengenai karya-karya Nietzsche setelah masa Elisabeth, adik Nietzsche, dan Lou Andreas-Salomé. Sebagaimana yang ditunjukkan oleh Penelope Deutscher dan Kelly Oliver, 'Sampai saat ini Kofman telah menjadi figur yang secara konsisten sulit dipahami, terkenal, tetapi sulit digolongkan dalam kajian-kajian Nietzsche' (1999a, p. 2). Hal tersebut disebabkan sebagian besar oleh gaya tafsiran sinkretisnya, menggabungkan perspektif psikoanalisis, dekonstruksi, dan feminis (di antaranya)." ${ }^{2}$

Minat Kofman pada Nietzsche dapat ditengarai sejak pertengahan 1960-an. Dan makin mendalam ketika Kofman mengerjakan disertasinya berjudul "Konsep Kebudayaan pada Nietzsche dan Freud" di Collège de France pada 1996 di bawah bimbingan Jean Hyppolite. Namun, wafatnya Hyppolite pada 1968 menjadikan Gilles Deleuze sebagai pembimbing Kofman. Pada saat itu, buku Nietəsche and Philosophy (1962) karya Deleuze memegang peranan penting dalam menumbuhkan minat "Nietzsche baru" di Prancis. Berdasarkan situasi tersebut, Kofman akan memanfaatkan "palingan linguistik" dalam penafsiran Nietzsche_-dan menjadi salah satu pengusung terpentingnya.

Selain Deleuze, filsuf lain yang sangat memengaruhi Kofman dalam membaca Nietzsche adalah Jacques Derrida. Kofman mengikuti seminarseminar Derrida di École Normale Supérieure dan dikenal sebagai bagian dari lingkaran Derrida di Prancis. Derrida menggambarkan sejarah "metafora dalam teks filsafat" dalam esainya berjudul "White Mythology". Wawasan tersebut dikembangkan secara khusus oleh Kofman dalam Nietasche and Metaphor (1972), buku pertamanya yang membahas tentang Nietzsche-hingga kematiannya, Kofman menulis lima buku tentang Nietzsche.

Projek Kofman dalam Nietssche and Metaphor adalah untuk menuliskan secara konseptual bahwa nilai sebuah konsep tidak lebih 
dari sebuah metafora. Bahkan, Kofman juga menyatakan bahwa sebuah konsep merupakan metafora-metafora yang diembunkan. ${ }^{3}$ Karena itu, projek Kofman adalah menuliskan metafora-metafora 'cair' sekaligus mengungkapkan metafora-metafora yang sudah tersurat dalam suatu tulisan melalui metode genealogis.

Meski demikian, posisi Kofman tidak serta-merta mengunggulkan metafora dibandingkan konsep. Pasalnya, mengunggulkan salah satu ranah merupakan jenis tirani yang patut dicela. Di satu sisi, tirani tampak ketika para filsuf memutlakkan nilai konseptual ketimbang nilai metaforis. Alhasil, penilaian yang benar selalu dilekatkan dengan sesuatu yang konseptual atau filosofis. Sebaliknya, hal-hal yang metaforis cenderung dinyatakan sebagai yang tidak benar atau tidak berguna.

Di sisi lain, tirani yang serupa juga muncul ketika para pemikir atau filsuf mengunggulkan nilai metafora belaka. Bagi Kofman, mengunggulkan masing-masing ranah hanya menegaskan bahwa para pemikir tersebut masih terjerat dalam sistem pemikiran metafisis. Oleh karena itu, Kofman menyatakan bahwa pokok penting untuk menjadi lebih Nietzschean adalah mampu berjarak dengan tulisan-tulisan yang konseptual dan metaforis, bahkan berani bermain dan bersenang-senang di antara keduanya. Berikut yang dinyatakan oleh Kofman:

"Entah tulisan itu bersifat konseptual atau metaforis (dan sejak Nietzsche, oposisi tersebut tidak diterapkan lagi), maka hal yang penting adalah dapat menertawakan oposisi tersebut, untuk dapat cukup berjarak dari macam tulisan tersebut dan bersenang-senang dengannya." ${ }^{4}$

Dengan demikian, Kofman seolah-olah hendak menyatakan tidak ada perbedaan yang sangat penting antara konsep dan metafora. Nilai sebuah konsep sama benarnya atau sama salahnya dengan nilai metafora. Pertanyaannya, mengapa Kofman mengambil posisi demikian? Untuk memahami posisi Kofman tersebut, kita perlu memahami pengertian 'nilai' dalam cakrawala pandang Kofman.

Dalam menafsir teks-teks Nietzsche, Kofman berkesimpulan bahwa sebuah nilai tidaklah bersifat benar atau salah. Nilai tidak ditentukan berdasarkan standar di luar ihwal yang dinilainya. Kalaupun hendak menggunakan standar kebenaran, pengertian kebenaran tersebut lebih bersifat praktis ketimbang metafisis. Bagi Kofman, menolak sebuah nilai karena nilai tersebut merupakan sesuatu yang salah adalah hal yang 
absurd. Pasalnya, nilai-nilai adalah syarat keberadaan manusia yang tidak dapat dipungkiri, melainkan hanya dapat diubah. Dengan kata lain, nilai merupakan keniscayaan. Selain itu, mengaitkan nilai dengan kebenaran berarti lupa untuk menempatkan diri "melampaui baik dan jahat".

Tafsiran Kofman tersebut didasarkan pada pembacaannya terhadap salah satu teks Nietzsche, yaitu Kasus Wagner (der Fall Wagner [W]), "Epilog". Berikut potongan teks $W$ tersebut:

"Bentuk-bentuk yang bertentangan dalam berbagai optik nilai samasama dibutuhkan: mereka adalah cara-cara untuk melihat, yang kebal terhadap penalaran-penalaran dan penolakan-penolakan. Seseorang tidak dapat menolak kekristenan; seseorang tidak dapat menolak suatu penyakit dari sang mata. Pesimisme demikian telah melawan seperti sebuah filsafat, yang merupakan betapa tingginya kepandiran yang terpelajar. Tampak bagiku konsep-konsep 'benar' dan 'tidak benar' tidak memiliki makna dalam optik-optik tersebut.- Satu-satunya yang harus ditolak adalah kepalsuan, yakni tipu daya insting yang menolak untuk mengalami pertentangan-pertentangan tersebut sebagai pertentanganpertentangan-." 5

Berdasarkan potongan teks tersebut, Kofman menyatakan bahwa nilai tidak pernah merujuk pada kebenaran. Bahkan, dalam tafsiran Kofman, Nietzsche menentangkan nilai dengan kebenaran. Pemeriksaan Nietzsche terhadap metafisika memperlihatkan bahwa kebenaran adalah sebuah fiksi yang dibutuhkan bagi makhluk hidup tertentu dan sebagai syarat keberadaan mereka. Bagi Kofman, salah satu temuan terbesar Nietzsche adalah gagasan bahwa pengetahuan mengacu pada kehidupan dan kebenaran mengacu pada kehendak kebenaran. Karena itu, persoalan nilai bukanlah ihwal metafisis, tetapi genealogis (afirmasi atau menolak kehidupan).

Kendati demikian, Kofman tidak berpendapat bahwa semua nilai bersifat setara. Bahkan, nilai-nilai yang berlaku secara de facto bukanlah nilai-nilai yang paling berharga secara de jure. Menurut Kofman, Nietzsche juga membangun sebuah hierarki nilai-nilai. Berikut yang dinyatakan oleh Kofman.

"Seandainya Nietzsche mengenalkan sebuah pemilahan antara nilainilai yang benar dan palsu, hal tersebut bukanlah demi kebenaran tentang kehidupan atau kebenaran tentang nilai, melainkan mengenai nilai bagi kehidupan, mengenai suatu tipe kehidupan tertentu dan masa depannya." 
Bagi Nietzsche, dalam tafsiran Kofman, nilai-nilai dipandang 'benar' karena mereka menunjukkan sebuah kehendak yang kuat untuk membutuhkan ketulusan atau mengakui secara gamblang bahwa ia membutuhkan ilusi. Selain itu, nilai-nilai memiliki kebenarannya apabila cocok dengan masa depan manusia, yakni memungkinkan ia untuk melampaui dirinya sendiri dalam gerak manusia melampaui. Sebaliknya, nilai-nilai dipandang 'salah' atau 'palsu' karena nilai-nilai tersebut menyelubungi asal-usul pembentukan dirinya yang bersifat manasuka dan menjadikan dirinya sebagai yang mutlak. Implikasinya, nilai-nilai mutlak tersebut menghalangi segala hal yang paling kuat untuk senantiasa bertumbuh. Pasalnya, mereka yang paling kuat menilai berdasarkan standar penilaiannya sendiri dan tidak tunduk pada moralitas universal apapun.

Nietzsche menyatakan bahwa frasa "tipu daya insting" dalam potongan teks $W$ di atas adalah tanda kepalsuan. Dalam konteks tersebut, Kofman menafsirkan bahwa tipu daya insting sebetulnya merupakan nir-nilai yang menjelma menjadi nilai-nilai akan kehidupan tertentu. Pasalnya, nilainilai tersebut sebetulnya tidak sungguh-sungguh hidup. Mereka menolak untuk membenarkan kehidupan dalam segala rupa dan kemajemukannya. Menurut Kofman, tipu daya tersebut merupakan kehendak yang memilih kematian atau alasan di balik tipu daya itu adalah demi mempertahankan kelangsungan hidup spesies.

Dengan demikian, Kofman menyimpulkan bahwa nilai yang palsu adalah segala macam hal yang menjelekkan, menyempitkan, dan memiskinkan kehidupan. Sebaliknya, nilai yang sebenarnya adalah nilainilai yang memperindah kehidupan dan yang memungkinkan seseorang untuk mencintai kehidupan (amor fati). Jadi, menurut Kofman, nilai dari suatu nilai-yang menentukan benar dan palsunya — selalu bergantung pada penghargaan atau perendahan kehidupan, bukan pada kebenaran. Atau, dalam rumusan yang lain, nilai dari suatu nilai terletak pada meningkat/merosotnya atau kelimpahan/kemiskinan kehidupan. Karena itu, Kofman menyatakan bahwa nilai yang benar maupun nilai yang palsu tidak ada sangkut pautnya dengan 'ada'. Keindahan hanyalah suatu projeksi ke dalam dunia mengenai berlimpahnya kekuatan dan tanda dari ia yang menilainya. Sebaliknya, keburukan merupakan simbol ketidakberdayaan dari ia yang menilainya.

Selanjutnya, Kofman menyatakan, "Hanya orang-orang yang bermoral ningrat atau luhur yang dapat menyadari ketiadaan kebenaran 
tanpa menjadi binasa." ${ }^{\prime 7}$ Hanya orang-orang seperti itulah yang mampu menghendaki bagi dirinya suatu ilusi atau suatu perspektif yang unik dan memalsukan realitas_-yang berbeda dengan orang-orang bermoral sahaya atau hina. Mengapa demikian? Karena keunikan tersebut merupakan tanda yang menunjukkan kekuatan afirmasi kehendak. Sebaliknya, orang-orang yang lemah akan binasa ketika mereka mengakui kerelatifan perspektifperspektifnya. Pasalnya, pengakuan atau penerimaan tersebut menuntut mereka untuk mengakui kesahihan penilaian-penilaian lain, khususnya nilai-nilai yang mereka benci. Untuk orang-orang yang kuat, memberikan selubung pada ilusi adalah hal yang tak berguna bagi kehidupan. Itulah sebabnya mereka mampu merefleksikan perspektifnya sebagai sebuah perspektif.

Berdasarkan tafsiran Kofman tersebut-sekurang-kurangnya dalam Nietzsche and Metaphor-dapat disimpulkan bahwa nilai tidak ada sangkut-pautnya dengan kebenaran. Namun, nilai-nilai tersebut memiliki 'kebenarannya' sendiri sejauh berguna bagi kehidupan: afirmasi terhadap kehidupan. Meski demikian, tafsiran Kofman menyingkap persoalan baru, yaitu: bagaimana menentukan nilai yang kuat (afirmasi kehidupan) dan nilai yang lemah (menolak kehidupan)? Pokok persoalan tersebut menjadi salah satu kritik yang dilontarkan oleh para penafsir Nietzsche generasi berikutnya, misalnya Maudemarie Clark.

\section{Maudemarie Clark}

Perhatian utama Maudemarie Clark mengenai Nietzsche mengarah pada dua hal pokok, yakni perihal kebenaran dan filsafat. Dua pokok tersebut tertuang dalam bukunya Nietasche on Truth and Philosophy (Cambridge: Cambridge University Press, 1990). Sebelum memulai analisisnya terhadap pemikiran Nietzsche, Clark mendeskripsikan secara karikatural beberapa pendekatan terhadap filsafat Nietzsche hingga tahun 1990-an, baik tradisi tradisionalis maupun "Nietzsche baru".

Clark memposisikan Kofman dalam tradisi "Nietzsche baru" yang berhaluan dekonstruktif. Salah satu ciri haluan tersebut adalah memandang berbagai kontradiksi dalam teks-teks Nietzsche bukan sebagai persoalan utama. Bahkan, kalangan dekonstruksionis mempertahankan ketegangan atau kontradiksi sebagai unsur utama dalam tafsiran-tafsirannya. Analisis Clark terhadap strategi Kofman menunjukkan bahwa salah satu doktrin 
Nietzsche, kehendak kuasa (der Wille zur Macht), merupakan hipotesis tentang penafsiran. Dengan kata lain, dalam strategi Kofman, kehendak kuasa adalah tafsiran-tafsiran kreatif atas kehidupan. Dan suatu tafsiran dapat dikatakan sebagai tafsiran yang sehat apabila tafsiran tersebut mengafirmasi kehidupan. Namun, persis pada posisi Kofman tersebut, Clark memperlihatkan bahwa salah satu kelemahan tafsiran Kofman adalah tidak menguraikan standar tafsiran-tafsiran yang mengafirmasi kehidupan.

Selanjutnya, berdasarkan analisisnya terhadap posisi Kofman maupun beberapa tradisi lainnya, Clark mendaku bahwa ia sendiri menerapkan pendekatan 'kombinasi' dalam menelaah pemikiran Nietzsche. Clark mengajukan sebuah tafsiran bahwa kendatipun Nietzsche menolak metafisika, tetapi ia mengafirmasi keberadaan kebenaran. Tafsiran tersebut diketengahkan oleh Clark dalam suatu iklim penafsiran yang menegaskan bahwa Nietzsche menolak keberadaan kebenaran. ${ }^{8}$ Seandainya pun Nietzsche mengakui keberadaan kebenaran, beberapa penafsir akan menyatakan bahwa Nietzsche terjebak pada "persoalan acuan diri (the problem of self-reference)". Maksudnya, seandainya pernyataan "Tidak ada kebenaran" adalah benar, apa yang dinyatakan oleh Nietzsche adalah salah karena ada sebuah kebenaran yang sedang disampaikan, yakni: tidak ada kebenaran. Sebaliknya, seandainya pernyataan "Tidak ada kebenaran" adalah salah, penegasan yang dinyatakan oleh Nietzsche sendiri adalah salah atau sia-sia.

Dalam situasi tersebut, Maudemarie Clark berupaya menyelamatkan Nietzsche dari tuduhan persoalan acuan diri dengan menunjukkan bahwa kendatipun Nietzsche menolak metafisika, ia tetap memercayai keberadaan kebenaran-kebenaran. Untuk mempertahankan tafsiran tersebut, Clark menempuh tiga strategi, yakni: (1) menjelaskan dakuan-dakuan Nietzsche yang menolak kebenaran, (2) menjelaskan keyakinan Nietzsche tentang pentingnya kebenaran, dan (3) menjelaskan kepaduan antara kritik Nietzsche terhadap metafisika dan doktrin-doktrin Nietzsche sendiri. Agar pembahasan tidak melebar, saya akan membatasi pembahasan Clark pada strategi pertama karena menyoroti esai WL. Secara karikatural, strategi Clark tersebut dapat diskemakan seperti yang tergambar di bawah. 
Tabel 1. Analisis Clark Mengenai Evolusi (teori) Kebenaran Nietzsche

\begin{tabular}{|c|c|c|}
\hline \multicolumn{3}{|c|}{$\begin{array}{l}\text { TESIS CLARK: } \\
\text { Nietzsche menolak metafisika, tetapi mengafirmasi keberadaan kebenaran- } \\
\text { kebenaran. [hlm. 21-2] }\end{array}$} \\
\hline STRATEGI & $\begin{array}{l}\text { UNSUR } \\
\text { POKOK }\end{array}$ & ARGUMENTASI \\
\hline \multirow{3}{*}{$\begin{array}{l}\text { Menjelaskan } \\
\text { segala } \\
\text { dakuan } \\
\text { Nietzsche } \\
\text { yang } \\
\text { menolak } \\
\text { segala } \\
\text { macam } \\
\text { kebenaran }\end{array}$} & $\begin{array}{l}\text { Teori } \\
\text { Korespondensi } \\
\text { Metafisis }\end{array}$ & $\begin{array}{l}\text { Penolakan Nietzsche pada segala macam } \\
\text { kebenaran didasarkan pada pengandaian } \\
\text { bahwa kebenaran bersifat metafisis, yakni } \\
\text { kesesuaian ihwal pada ihwal-dalam-dirinya } \text { (realisme }_{\mathrm{m}} \text { ) [hlm. 22, 40-1]. Karena itu, } \\
\text { Nietzsche menyimpulkan tidak ada }_{\text {kebenaran (antirealisme }} \text { ) [hlm. 51, 61]. }\end{array}$ \\
\hline & Tesis Pemalsuan & $\begin{array}{l}\text { Berdasarkan teks } W L \text {, kebenaran adalah } \\
\text { ilusi karena 'kebenaran' yang dihasilkan } \\
\text { manusia tidak berkorespondensi dengan } \\
\text { ihwal-dalam-dirinya [hlm. 82-3]. Pasalnya, } \\
\text { 'kebenaran' (pengetahuan) manusia } \\
\text { bersifat terbatas (tautologis) [hlm. 87- } \\
\text { 8] sehingga memalsukan realitas (tesis } \\
\text { pemalsuan). Namun, posisi awal tersebut } \\
\text { akan ditinggalkan oleh Nietzsche } \\
\text { karena tidak ada dakuan mengenai tesis } \\
\text { pemalsuan dalam enam karya terakhirnya } \\
\text { [GM, W, GD, } A, E H \text {, dan NW] [hlm. } \\
103,108-9] .\end{array}$ \\
\hline & Perspektivisme & $\begin{array}{l}\text { Untuk melampaui tesis pemalsuan } \\
\text { tersebut, Nietzsche menawarkan } \\
\text { perspektivisme. Berdasarkan aforisme- } \\
\text { aforisme } G M \text {, perspektivisme merupakan } \\
\text { sebuah ungkapan metaforis Nietzsche } \\
\text { untuk mengatasi tesis pemalsuan [hlm. } \\
127-8,158] .\end{array}$ \\
\hline
\end{tabular}


Argumentasi utama dalam strategi pertama Clark adalah memaparkan bahwa ada palingan posisi ${ }^{9}$ Nietzsche mengenai kebenaran: mengakui keberadaan realitas metafisis (periode awal) dan menolak keberadaan realitas metafisis (periode akhir). Pada karya-karya awalnya, misalnya $W L$, Nietzsche menolak kebenaran dan memandangnya sebagai ilusi. Alasannya, kebenaran-kebenaran selalu bercorak antropomorfis dan tautologis. Dengan kata lain, kebenaran tidak pernah merujuk pada realitas sebagaimana adanya. Oleh sebab itu, kebenaran atau pengetahuan manusia selalu memalsukan realitas_-yang diistilahkan oleh Clark sebagai tesis pemalsuan.

Kendati demikian, Clark menengarai bahwa penolakan Nietzsche terhadap kebenaran sebetulnya didasarkan pada sebuah asumsi kebenaran korespondensi metafisis, yakni kesesuaian ihwal dengan ihwal-dalamdirinya (das Ding an sich). Clark akan menyejajarkan posisi Nietzsche tersebut dengan kosakata dari filsafat analitik, yakni antirealisme ${ }_{\mathrm{m}}{ }^{10}$ Sederhananya, dalam pandangan Clark, Nietzsche menolak keberadaan suatu kebenaran yang mandiri dari kemampuan akal budi maupun hasrat manusia. Sekurang-kurangnya terdapat dua alasan untuk menolak realisme ${ }_{\mathrm{m}}$ tersebut: (1) karena kebenaran yang demikian bersifat metafisis dan (2) karena kebenaran yang demikian mustahil dicukupkan oleh kemampuan akal budi manusia.

Di sisi lain, Clark juga berpendapat, "Posisi awal Nietzsche mengenai kebenaran tidak konsisten secara inheren."11 Pasalnya, tesis pemalsuan

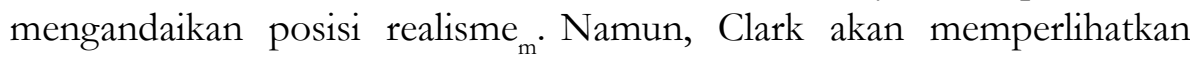
bahwa tesis pemalsuan akan ditinggalkan oleh Nietzsche pada periodeperiode akhir hidupnya, khususnya dalam enam karya terakhirnya: zur Genealogie Moral, der Fall Wagner, Götzen-Dämmerung, der Antichrist, Ecce Homo, dan Nietzsche contra Wagner. ${ }^{12}$ Demikian yang dinyatakan oleh Clark,

"Karena itu, enam buku terakhir Nietzsche tidak memberikan bukti terhadap tesis pemalsuan, tidak ada alasan untuk menolak komitmennya mengenai kemungkinan kebenaran di dalam ilmu pengetahuan, atau tidak juga kebenaran di dalam teori-teorinya sendiri. Dibandingkan dengan karya-karya sebelumnya, posisi ini tampak menakjubkan dan membutuhkan penjelasan. Saya mendapati bahwa penjelasan yang paling masuk adalah bahwa Nietzsche mengabaikan tesis pemalsuan ini karena ia menyadari bahwa pendapatnya mengenai ihwal-dalam-dirinya sebagai sebuah paradoks/antinomi menghilangkan segala landasan bagi tesis pemalsuan. [...] Nietzsche membutuhkan waktu 
untuk menyadari bahwa penolakannya terhadap kebenaran bergantung pada asumsi mengenai ihwal-dalam-dirinya."13

Dengan demikian, penghapusan tesis pemalsuan menjadikan posisi Nietzsche lebih konsisten. Bagi Clark, posisi akhir tersebut menegaskan bahwa Nietzsche menolak kebenaran metafisis secara mutlak dan konsisten. Implikasinya, dunia empiris atau penampakan tidak lagi dipandang sebagai ilusi. Clark mendasarkan analisisnya pada teks GD berjudul "Bagaimana 'Dunia Sejati' Pada Akhirnya Menjadi Mitos [Wie die ,wabre Welt” endlich zur Fabel wurde]". Secara sederhana, alur argumentasi Clark dapat dirumuskan sebagai berikut: seandainya Nietzsche menolak ihwal-dalam-dirinya, maka kebenaran tidak lagi menyembunyikan dirinya_alias dapat diakses. Dan seandainya kebenaran tidak lagi tersembunyi, ia harus ada di sana sehingga semua orang dapat mengaksesnya. Karena itu, alat-alat indera, kata, atau konsep tidak lagi menghasilkan pengetahuan yang memalsukan realitas, melainkan pengetahuan yang benar. Jadi, penolakan Nietzsche terhadap tesis pemalsuan berarti mengafirmasi kebenaran.

Namun, Clark juga menyadari bahwa kebenaran bersifat majemuk. Pasalnya, kapasitas pengetahuan manusia bersifat terbatas dibandingkan dengan realitas yang dihadapinya. Oleh karena itu, tiap orang dengan hasrat dan kepentingan yang berbeda akan menemukan kebenaran yang berbeda pula. Dengan kata lain, hasrat dan kepentingan tertentu akan menentukan titik pijak dan kebenaran tertentu pula. Hasrat dan kepentingan itulah yang diistilahkan oleh Nietzsche, dalam pembacaan Clark, sebagai perspektivisme. Clark menyatakan, "Perspektivisme merupakan ungkapan metaforis tentang apa yang saya sebut sebagai posisi neo-Kantian Nietzsche terhadap kebenaran, yaitu bahwa selalu ada lebih banyak kebenaran dibandingkan manusia yang mengetahuinya."

Bagi Clark, perspektivisme Nietzsche merupakan sebuah piranti retorika untuk mengatasi tesis pemalsuan yang merendahkan pengetahuan manusia. Melalui perspektivisme, pengetahuan tidak lagi memalsukan realitas. Namun, pengetahuan cocok dengan penafsiran-penafsiran yang tepat dan tidak terjebak pada persoalan acuan diri. Berdasarkan analisis tersebut, Clark juga menegaskan bahwa meskipun kebenaran bersifat perspektif, tetapi tidak berarti setiap dakuan-dakuan yang bertentangan dengannya juga bernilai benar.

Dengan demikian, Clark menegaskan bahwa Nietzsche mengakui 
keberadaan kebenaran. Namun di sisi lain, penafsiran Clark tersebut mengandung suatu kelemahan mendasar, khususnya mengenai palingan posisi (Kehre) kebenaran pada Nietzsche. Pasalnya, pada Nachlaß periode 1887 dan 1888, Nietzsche justru tidak mengabaikan tesis pemalsuan. ${ }^{15}$ Bornedal berpendapat bahwa pendekatan Clark — sebagaimana pendekatan Analitis pada umumnya - kurang tepat dalam menjelaskan pandanganpandangan epistemologis Nietzsche, meskipun mereka memiliki kepekaan hermeneutis yang cukup tinggi. Pasalnya, analisis silogisme tidak cocok untuk memperlihatkan kerumitan konsep-konsep Nietzsche yang bersifat 'mengambang' (floating meaning). ${ }^{16}$ Walhasil, konsep-konsep Nietzsche yang rumit pasti akan dibaca sebagai kontradiksi atau persoalan acuan diri. Dan projek seorang pembaca yang simpatik-dalam hal ini Clark-adalah menemukan 'kecocokan' yang logis mengenai posisi Nietzsche dalam kerangka analitis.

Pada bagian selanjutnya saya menawarkan sebuah pendekatan lain untuk menafsirkan pernyataan Nietzsche bahwa "kebenaran adalah metafora".

\section{Kebenaran adalah Metafora}

Saya menggali konsep 'metafora' Nietzsche dalam kekhasan sistem berpikir dan konteksnya. Dalam WL, Nietzsche menyatakan,

"Pertama-tama suatu rangsangan syaraf dialihkan [übertragen] menjadi suatu citra [ein Bild]! Metafora pertama. Citra tersebut kemudian ditransformasikan [nachgeformt menjadi suara! Metafora kedua. Dalam tiap kasus, terdapat lompatan dari suatu ranah menuju ranah yang berbeda dan baru." 17

Berdasarkan teks tersebut Nietzsche menyatakan bahwa terdapat dua jenis atau tahapan metafora. Dalam metafora tahap pertama, Nietzsche menyejajarkan konsep 'metafora' dengan 'pengalihan' [Übertragung. ${ }^{18}$ Maksudnya, pengalihan sudah selalu melibatkan aktivitas perpindahan dari ranah, tatanan, atau dunia yang satu menuju ranah, tatanan, atau dunia yang lain. Jadi, dalam metafora tahap pertama terjadi perpindahan dari ranah rangsangan syaraf menuju ranah citra atau gambaran.

Hal serupa juga terjadi dalam metafora tahap kedua, yakni peralihan dari sistem yang satu menuju sistem yang lain. Kendati demikian, konotasi makna 'metafora' dalam tahap kedua lebih merujuk pada 'transformasi' atau 
"aktivitas perubahan rupa/bentuk" [nachgeformt]. Pasalnya, perpindahan tersebut juga melibatkan semacam perubahan tatanan, yakni dari dunia citra, gambaran, atau imaji menjadi dunia suara, bunyi, atau kata.

Untuk membayangkan pengalihan dan transformasi tersebut, saya merekayasa ilustrasi yang diberikan Nietzsche dalam $W L$. Andaikan bahwa ada seorang anak kecil diajarkan bahwa "batu itu keras" oleh orangtuanya. Suatu ketika si anak kecil tersebut menemukan sebongkah bentuk padat tergeletak di tepi jalan. Setelah ia mengamati cukup lama, ia menyadari bahwa di tepi jalan tersebut terdapat pula bongkahan-bongkahan padat lainnya yang memiliki ciri khas yang sama dengan bongkahan pertama, yakni kekerasannya. Namun, ia juga menyadari bahwa jenis dan bentuk bongkahan-bongkahan padat tersebut bermacam-macam, meskipun memiliki sifat keras yang relatif sama. Kemudian, setelah berdiam beberapa saat ia menyimpulkan, "Batu itu keras."

Dalam ilustrasi karikatural di atas tergambar dua tahap cara kerja metafora. Pertama, berbagai rupa bongkahan padat yang tergeletak di jalan merangsang alat-alat indera (penginderaan) si pengamat untuk mengalihkan berbagai rangsangan syaraf tentang batu menjadi suatu gambaran atau representasi visual tentang batu. Kedua, gambaran atau citra visual tentang batu tersebut kemudian diungkapkan atau diterjemahkan oleh si pengamat ke dalam dimensi suara/bunyi yang sangat berbeda dengan dimensi visual, yakni dengan pernyataan: "batu itu keras".

Berdasarkan cara kerja metafora tersebut, Nietzsche hendak menegaskan bahwa fungsi metafora adalah pengalihan dari dimensi yang satu ke dimensi yang lain. Namun, Nietzsche juga menyatakan bahwa pengalihan tersebut bersifat manasuka karena tidak ada kesesuaian realitas antara ranah pengganti dan ranah yang digantikannya. Nietzsche menggambarkan sifat manasuka dari pengalihan ganda tersebut dalam penyelidikannya mengenai konsep 'kata'. Demikian ia menulis:

"Apa itu sebuah kata [Was ist ein Wort]? Citra [gambaran] suatu rangsangan syaraf dalam bunyi [Die Abbildung eines Nervenreizes in Lauten]. Namun, untuk menyimpulkan lebih lanjut dari rangsangan syaraf [ada] suatu penyebab di luar diri kita sudah merupakan suatu hasil penerapan yang salah dan tidak dapat dibenarkan berdasarkan prinsip kecukupan nalar [Satzes vom Grunde]. Seandainya kebenaran itu sendiri telah menjadi faktor penentu dalam pembentukan bahasa, dan seandainya titik pijak kepastian telah menjadi penentu penamaan, maka bagaimana mungkin kita masih berani mengatakan, "Batu itu keras [der 
Stein ist hart]," seolah-olah "keras" [,hart”] adalah sesuatu yang tidak akrab dengan kita dan bukan suatu rangsangan yang sungguh-sungguh subjektif [eine ganz subjektive Reizung] belaka! Kita memisahkan hal-ihwal [theilen die Dienge] berdasarkan gender [Geschlechtern], kita menamakan pohon sebagai maskulin [bezeichnen den Baum als männlich] dan tanaman sebagai feminin [die Pflanze als weiblich]: betapa manasukanya pengalihanpengalihan itu [welche willkürlichen Übertragungen]!"19

Berdasarkan potongan esai di atas, Nietzsche menunjukkan bahwa predikat 'keras' dalam kalimat "Batu itu keras" bersifat manasuka bahkan manusiawi. Seolah-olah kata 'keras' bersifat objektif sehingga dapat dikenakan pada subjek bernama 'batu' serta dianggap benar atau sesuai dengan realitas sebagaimana adanya. Dengan kata lain, kata 'keras' merupakan representasi atas sifat keras (ke-keras-an) batu yang dipersepsi oleh manusia itu sendiri, khususnya indera peraba. Melalui contoh tersebut, Nietzsche menggarisbawahi bahwa hubungan manusia dengan batu bersifat manusiawi. Atau, dalam rumusan lain: realitas batu sebagaimana adanya tidaklah keras atau lembut, tetapi batu itu terasa keras berdasarkan sentuhan atau rabaan manusia. Dan seandainya pengetahuan bahwa "batu itu keras" dipegang atau diyakini sebagai hal yang benar (Führwabrhalten $)^{20}$, maka kebenaran itu pun bersifat manusiawi atau antropomorfis.

Dengan demikian, ketika Nietzsche menyatakan bahwa citra adalah sebuah metafora pertama, hal itu berarti bahwa citra adalah sebuah tanda ${ }^{21}$ inderawi yang bersifat manasuka dan berbeda dengan rangsangan syaraf. Ringkasnya, tidak ada kesesuaian visual antara rangsangan dan citra. Begitu pula halnya dengan metafora kedua. Sifat manasuka tersebut digambarkan melalui peralihan-sekaligus perubahan tatanan-dari dimensi visual menjadi menjadi dimensi bunyi. Sederhananya, manusia menamakan citra yang terbentuk. Misalnya, gambaran atau citra tentang batu (kebatuan) dinamakan sebagai 'batu'. Penamaan tersebut bersifat manasuka karena tatanan kombinasi bunyi berbeda dengan tatanan citra yang terbentuk. Bahkan, sifat manasuka tersebut juga dapat ditemukan ketika seseorang menamakan sebuah kualitas pada citra bersangkutan, walaupun kualitas tersebut tidak ada kaitan secara langsung dengan rangsangan syarafnya. Misalnya, kata 'keras' yang disematkan pada 'batu'.

Selain itu, Nietzsche juga menunjukkan bahwa sifat manasuka tampak dalam penamaan benda-benda dengan ciri khas gender tertentu. Dalam struktur bahasa Jerman terdapat tiga jenis gender untuk menamakan kata benda, yakni: maskulin, feminin, dan netral—secara umum ditengarai 
dengan penggunaan partikel der, die, dan das yang mendahului kata bendanya. Nietzsche menunjukkan sifat manasuka tersebut dengan mengilustrasikan bagaimana citra pohon dialihkan dalam kata 'pohon' yang bergender maskulin, 'der Baum'. Atau, bagaimana pula citra tanaman ditransformasikan dalam kata 'tanaman' yang bergender feminin, 'die Pflanze'. Berdasarkan paparan Nietzsche tersebut, dapat disimpulkan bahwa metafora mengandaikan dua tahap pengalihan yang bersifat manasuka, yakni: pengalihan dari rangsangan syaraf menuju tanda inderawi dan pengalihan dari tanda inderawi menuju tanda linguistik (bahasa).

Lantas, bagaimana metafora berubah menjadi ilusi? Dalam potongan teks di atas, Nietzsche juga menyatakan bahwa "kebenaran-kebenaran adalah ilusi-ilusi yang telah kita lupakan sebagai ilusi-ilusi". Dalam pernyataan tersebut Nietzsche tidaklah sedang menciptakan atau mempostulatkan sebuah teori tentang kebenaran. Namun, Nietzsche justru sedang mendiagnosis bahkan membedah konsepsi kebenaran yang telah ada. Klausa penjelas "yang telah seseorang lupakan sebagai ilusi-ilusi (von denen man vergessen hat)" menegaskan diagnosis Nietzsche. Dengan kata lain, Nietzshe tidak sedang menciptakan teori bahwa "kebenarankebenaran adalah ilusi-ilusi", tetapi memperlihatkan bahwa apa yang dipercayai orang-orang sebagai kebenaran tidak lain adalah ilusi yang telah mereka lupakan sebagai ilusi.

Dalam pernyataan tersebut, Nietzsche memaksudkan bahwa berbagai macam hal yang kita pegang atau yakini sebagai kebenaran pada dasarnya adalah metafora-metafora yang telah dilupakan sebagai metafora oleh manusia itu sendiri. Malah, manusia memandang metafora-metafora yang telah dilupakan sebagai metafora tersebut sebagai hal-ihwal yang harfiah atau nyata. Padahal, metafora-metafora itu sendiri adalah pengalihanpengalihan yang tidak ada kesesuaiannya dengan realitas sebagaimana adanya. Dalam pengertian itulah kebenaran menjadi ilusi.

Nietzsche mengilustrasikan situasi tersebut dengan mengibaratkan kebenaran-kebenaran sebagai koin-koin. Sebuah koin dipandang berguna atau bernilai karena memiliki fungsi atau kekuatan figuratif yang terukir pada sisi-sisinya. Sebaliknya, sebuah koin yang telah kehilangan tatahan ukirannya tidak ada bedanya dengan sebuah logam belaka. Demikian pula halnya dengan metafora. Berbagai metafora yang telah kehilangan atau terlupakan sifat metaforisnya tidak lagi dapat disebut sebagai metafora. Dan 
seiring waktu metafora-metafora 'usang' tersebut telah berubah menjadi sejenis bahasa yang telah dibakukan, dipadatkan, atau dikoagulasikan untuk merepresentasikan realitas secara harfiah dan langsung_-alias metafisika. Metafora-metafora jenis demikian telah kehilangan fungsi simbolisnya dan telah direduksi menjadi bahasa denotasi. Singkatnya, jenis bahasa seharihari yang digunakan oleh manusia saat ini adalah metafora usang (mati) itu sendiri.

Jika demikian, apakah pemeriksaan genealogis Nietzsche terhadap kebenaran-kebenaran antropomorfis meniadakan Kebenaran? Kofman telah menunjukkan bahwa tidak ada gunanya menautkan penilaian dengan kebenaran. Pasalnya, Kofman telah meradikalkan konsepsi metafora Nietzsche sehingga tidak ada lagi perbedaan nilai antara konsep dan metafora. Dengan kata lain, bahasa yang kita gunakan selalu bersifat metaforis.

Posisi tafsir semacam Kofman yang cenderung hiperbolis merupakan unsur yang khas dalam pendekatan dekonstruktif. Bahkan, Jacques Derrida dalam esainya berjudul "White Mythology" (Sussex: The Harvester Press, 1982) berani mendaku bahwa semua filsafat telah terinfeksi suatu kebutaan akan unsur metaforis di dalam bahasa. Bagi Derrida, metafora lebih dari sekadar sebuah efek khusus di dalam bahasa. Malahan, metafora adalah esensi bahasa itu sendiri. Implikasinya, seluruh wacana filsafat merupakan suatu bangunan filosofis yang dibangun tanpa didasarkan pada realitas sebagaimana adanya. ${ }^{22}$ Dan hal tersebut menandakan kematian filsafat sebagai upaya untuk merefleksikan Kebenaran.

Dalam sudut pandang tertentu, tafsiran Kofman dan Derrida mungkin cocok dengan kritik genealogis Nietzsche terhadap persoalan kebenaran, metafisika, atau filsafat. Namun di sisi lain, Nietzsche sendiri tampaknya tidak serta-merta berupaya menghilangkan Kebenaran dalam wacana filosofisnya. Setidak-tidaknya, ketika Nietzsche menyatakan, "Tidak ada 'kebenaran',' pernyataan tersebut mengimplisitkan bahwa tidak ada suatu standar ultimat, baku, dan abadi bagi Kebenaran. ${ }^{23}$ Pasalnya, Nietzsche menengarai bahwa 'kebenaran' sudah selalu berupaya untuk membakukan atau mengabadikan Kebenaran. Hal tersebut terjadi karena bahasa yang digunakan sudah selalu mengandaikan asumsi-asumsi metafisis tertentu. Oleh karena itu, Kebenaran selalu luput dari segala analisis mutakhir manusia mengenainya. 
Barangkali, secara karikatural, salah seorang penafsir yang berhasil membahasakan secara positif kegelisahan Nietzsche mengenai Kebenaran adalah Paul Ricoeur. Pasalnya, Ricoeur membukakan dimensi lain tentang metafora yang diabaikan oleh Derrida. Bagi Ricoeur bahasa bukanlah sekadar metafora yang telah dilupakan sebagai metafora-atau yang diistilahkan Ricoeur sebagai "metafora yang mati". Namun, Ricoeur mengenalkan dimensi "metafora yang hidup"-atau kemampuan untuk menciptakan metafora yang baru-sehingga bahasa dapat mengembangkan kapasitas pengetahuan manusia. Dalam Rule of Metaphor (London and New York: Routledge, 2003), Ricoeur menyatakan bahwa metafora yang hidup menyulut imajinasi manusia untuk berpikir lebih lagi. ${ }^{24}$ Dengan demikian, metafora yang hidup mengajak tiap orang untuk terlibat dalam hermeneutika - sebagai perjumpaan antara Kebenaran dan kebenaran subjektif si penafsirnya.

Posisi Ricoeur tersebut sedikit banyak mengingatkan pada nasihat Nietzsche sendiri untuk membaca tulisan-tulisan aforismenya melalui suatu seni tafsir. Dalam Genealogi Moral (GM), "Kata Pengantar", \$8, Nietzsche menyatakan,

"Sebuah aforisme (yang dicap dan dibentuk dengan sepantasnya) tidak pernah 'dipecahkan' ketika hanya dibaca begitu saja; namun, kita perlu memulai eksegesis, karena itulah dibutuhkan suatu seni eksegesis. [...] Sudah barang tentu, satu hal menjadi niscaya di atas segala hal lainnya seandainya kita membaca sebagai suatu seni dalam cara ini, sesuatu yang sudah tidak dipelajari lagi secara mendalam akhir-akhir ini-dan karena itu akan membutuhkan beberapa waktu sebelum tulisan-tulisan saya "dapat dibaca"—sesuatu yang menjadikan kita hampir seperti seekor sapi dan bukan seorang "manusia modern": memamah biak." 25

Dalam konteks itulah Nietzsche berupaya mengingatkan kembali fungsi simbolis atau figuratif yang terdapat dalam bahasa. ${ }^{26}$ Salah satu upaya serius nan kreatif dari Nietzsche untuk 'menghidupkan' kembali metafora adalah dengan mengembangkan gaya tulisan khasnya yang berjenis aforistik. Tidak hanya itu, Nietzsche pun sangat berhati-hati dalam merancang, memilih, dan menggunakan kata dalam mengerjakan projekprojek bukunya. ${ }^{27}$ Oleh karena itu, keseriusan Nietzsche dalam berfilsafat atau pun refleksinya mengenai kebenaran mengkristal dalam aforismeaforismenya. Salah satu contohnya adalah pengandaian metaforis bahwa 
"kebenaran adalah seorang perempuan" sebagaimana yang tertera dalam $J G B$, "Kata Pengantar", $\mathbb{} 1 .^{28}$

\section{Simpulan}

Dengan demikian, potongan esai WL yang menyatakan "kebenaran adalah metafora" atau "kebenaran adalah ilusi" merupakan konstatasi diagnosis Nietzsche mengenai kebenaran yang telah ada di zamannya. Artinya, berbagai macam kebenaran yang diyakini oleh manusia tidak lain adalah berbagai macam ilusi yang telah dilupakan sebagai ilusi. Analisis Nietzsche juga memperlihatkan bahwa kebenaran adalah metafora atau pengalihan yang tidak bersesuaian langsung dengan realitas sebagaimana adanya.Bahkan, metaforaadalah semacampemanusiaan (antropomorfisme) terhadap realitas yang dihadapinya. Walhasil, kebenaran adalah ilusi yang telah dilupakan sebagai ilusi dan dipegang atau diyakini sebagai realitas yang sesungguhnya.

Menariknya, pernyataan Nietzsche tersebut memunculkan berbagai tafsiran mengenai posisi dan sikap Nietzsche terhadap kebenaran. Di satu sisi, Kofman menafsirkan bahwa pembicaraan mengenai kebenaran tidak relevan dalam filsafat Nietzsche. Pasalnya, nilai tidak ada sangkut-pautnya dengan kebenaran. Menurut Kofman, pokok penting metafora (nilai) adalah kegunaannya untuk mengafirmasi kehidupan dengan sehat. Di sisi lain, Clark memperlihatkan bahwa pada akhirnya Nietzsche menolak kebenaran metafisis (ihwal-dalam-dirinya), tetapi tetap mengafirmasi keberadaan kebenaran. Analisis Clark tersebut didasarkan pada palingan posisi (Kehre) Nietzsche terhadap kebenaran.

Di samping kedua tafsiran tersebut, saya menawarkan sebuah posisi tafsir bahwa Nietzsche tidak serta-merta meniadakan kebenaran. Upaya Nietzsche untuk menghidupkan kembali unsur simbolis dan figuratif dalam bahasa mengimplisitkan bahwa kebenaran sudah selalu lolos dalam berbagai jenis 'kebenaran' manusiawi. Dalam konteks itulah, membaca teks-teks aforistik Nietzsche secara hati-hati dan teliti memungkinkan para penafsir untuk berjumpa dengan Kebenaran. 


\section{Bibliography}

Bornedal, Peter. The Surface and the Abbys. Berlin and New York: Walter de Gruter, 2010.

Breazeale, Daniel, ed. Philosophy and Truth: Selections from Nietzsche's Notebooks of the Early 1870's. London: Humanities Press, 1993.

Clark, Maudemarie. Nietssche: On Truth and Philosophy. Cambridge: Cambridge University Press, 1990.

Colli, Giorgio dan Mazzino Montinari, eds. "Ueber Wahrheit und Lüge im aussermoralischen Sinne.” In Die Geburt der Tragödie. Un₹eitgemäße Betrachtungen I-IV. Nachgelassene Schriften 1870-1873: Kritische Studienausgabe Band 1, 873-90. Berlin: Walter de Gruyter, 1988.

Crawford, Claudia. The Beginnings of Nietssche's Theory of Language. Berlin: Walter de Gruyter, 1988.

Derrida, Jacques. "White Mythology." In Margins of Philosophy. Translated by Alan Bass. Sussex: The Harvester Press, 1982.

Grimm, Ruediger H. Nietsshce's Theory of Knowledge. Berlin: Walter de Gruyter, 1977.

Heidegger, Martin. Nietssche: Erster Band. Frankfurt am Main: Vittorio Klostermann GmbH, 1996.

- Nietasche, Volume III: The Will to Power as Knowledge and as

Metaphysics. Translated by Joan Stambaugh, David Farell Krell, and

Frank A. Capuzzi. San Francisco: Harper \& Row, Publisher, Inc., 1987.

Hollingdale, R. J. Introduction to Twilight of the Idols and Antichrist. London: Penguin Books, 1968.

Kaufmann, Walter. Basic Writing of Nietzsche. New York: Modern Library, 2011.

Kofman, Sarah. Nietzsche and Metaphor. Translated by Duncan Large. London: Athlone Press, 1993.

Large, Duncan. "Kofman's Nietzsche.” In Interpreting Nietzsche: Reception and Influence, edited by Ashley Woodward, 116-30. London and New York: Continuum, 2011.

Nietzsche, Friedrich. Beyond Good and Evil. Translated by Walter Kaufmann.

New York: Vintage Books, 1966. . The Gay Science: With a Prelude in Rhymes and an Appendix of 
Songs. Translated by Walter Kaufmann. New York: Vintage Books, 1974.

The Will to Power. Translated by Walter Kaufmann and R. J. Hollingdale. New York: Vintage Books, 1968.

Ricouer, Paul. The Rule of Metaphor. Translated by Robert Czerny, Kathleen

McLaughlin, and John Costello. London and New York: Routledge, 2003.

Wibowo, A. Setyo. Gaya Filsafat Nietzsche. Yogyakarta: Galang Press, 2004.

\section{Endnotes:}

1 "What then is truth? A movable host of metaphors, metonymies, and anthropomorphisms: in short, a sum of human relations which have been poetically and rhetorically intensified, transferred, and embellished, and which, after long usage, seem to a people to be fixed, canonical, and binding. Truths are illusions which we have forgotten are illusions; they are metaphors that have become worn out and have been drained of sensuous force, coins which have lost their embossing and are now considered as metal and no longer as coins." Daniel Breazeale, Philosophy and Truth (London: Humanities Press, 1993) 84. Kurung siku dan cetak tebal di atas oleh saya, diterjemahkan dari Giorgio Colli and Mazzino Montinari, Kritische Studienausgabe Band 1 (Berlin: Walter de Gruyter, 1988) 880-1.

2 "Amid the wealth and diversity of her productivity, though, Kofman also established herself as the most significant and authoritative female interpreter of Nietzsche's work since the days of his sister Elisabeth and Lou Andreas-Salomé. As Penelope Deutscher and Kelly Oliver point out, 'Kofman has been a consistently elusive figure, well known but hard to classify within Nietzsche studies' (1999a, p.2). This is largely on account of her syncretistic style of interpretation, merging psychoanalytic, deconstructive and feminist perspectives (among others)." Duncan Large, "Kofman's Nietzsche", Interpreting Nietzsche: Reception and Influence, ed. Ashley Woodward (London and New York: Continuum, 2011) 116.

3 Ibid., 3.

4 "Whether writing is conceptual or metaphorical (and since Nietzsche the oposition has hardly applied any longer), the essential thing is to be able to laugh at it, to be at enough of a distance from it to make fun of it." Ibid., 3.

5 "These opposite forms in the optics of value are both necessary: they are ways of seeing, immune to reasons and refutations. One cannot refute Christianity; one cannot refute a disease of the eye. That pessimism was fought like a philosophy, was the height of scholarly idiocy. The concepts 'true' and 'untrue' have, as it seems to me, no meaning in optics.-What alone should be resisted in that falseness, that deceitfulness of instinct which refuses to experience these opposites as opposites-." Walter Kaufman, Basic Writing (New York: Modern Library, 2011) 647.

6 "If Nietzsche introduces a distinction between true and false values it is not in the name of the truth of life or the truth of value, but of value for life, of a certain type of life and its future." Kofman, op. cit., 126.

$7 \quad$ Ibid., 132.

8 Beberapa aforisme yang sering dikutip untuk menyatakan bahwa Nietzsche menolak 
kebenaran, di antaranya: "[K]ebenaran-kebenaran merupakan ilusi-ilusi yang kita lupakan sebagai ilusi (Breazeale, op. cit., 84 [Colli and Montinari, op. cit., 880-1])", "[K] ebenaran merupakan semacam kekeliruan yang tanpanya spesies mahkluk tertentu tidak dapat hidup (WM, \$493)", dan "[T]idak ada fakta-fakta, ... hanya tafsiran-tafsiran (WM, \$481)". Kendati pernyataan-pernyataan Nietzsche yang menolak kebenaran berasal dari Nachlaß, karya-karya yang diterbitkan Nietzsche pun menegaskan pokok yang sama. Misalnya, Nietzsche menyatakan bahwa pada dasarnya kita tidak memiliki organ untuk pengetahuan [das Erkennen] atau "kebenaran" (FW, §354), mendaku bahwa tiap orang tidak dapat hidup tanpa suatu "pemalsuan yang ajek tentang dunia melalui angka-angka $(J G B, \$ 4)$ " dan bahkan fisika merupakan "suatu penafsiran belaka mengenai dunia dan bukan penjelasan (JGB, \$14)". Nietzsche juga berpendapat bahwa kemampuan terbaik ilmu pengetahuan hanya "menyederhanakan, melalui dunia yang artifisial, dikonstruksi, dan cocok dengan dunia yang telah dikelirukan (JGB, \$24)" dan "bukankah dunia yang menjadi perhatian kita adalah suatu fiksi? (JGB, \$34)". Beberapa aforisme WM saya kutip dari Friedrich Nietzsche, The Will to Power, trans. Walter Kaufmann and R. J. Hollingdale (New York: Vintage Books, 1968), sedangkan aforisme $F W$ merujuk pada Friedrich Nietzsche, The Gay Science: With a Prelude in Rhymes and an Appendix of Songs, trans. Walter Kaufmann (New York: Vintage Books, 1974), dan aforisme JGB saya kutip dari Friedrich Nietzsche, Beyond Good and Evil, trans. Walter Kaufmann (New York: Vintage Books, 1966).

9 Peter Bornedal dalam The Surface and the Abbys mencatat beberapa komentator yang menunjukkan perkembangan perubahan posisi kebenaran sebagai suatu palingan/ pembalikan (Kehre) dalam pemikiran Nietzsche adalah Alexander Nehamas dalam Nietzsche: Life as Literature (Cambridge and London: Harvard University Press, 1985, hal. 43) dan Maudemarie Clark op. cit., 95. Selain itu, sebagian komentator juga berpendapat bahwa Nietzsche dalam posisi akhirnya juga membuang konsepsi yang sering diulangnya, yakni alat-alat indera atau konsep-konsep memalsukan realitassebuah konsepsi yang diberi nama "tesis pemalsuan (falsification thesis)" Nietzsche (dalam Maudemarie Clark) atau "teori kekeliruan (error-theory)" (dalam Martin Steven Green). Peter Bornedal, The Surface and the Abbys (Berlin: Walter de Gruyter, 2010) 104.

10 "According to the anti-realis $s_{m}$ attribute to Nietzsche, truth's independence of human beings amount to the possibility of a gap between our (cognitive) abilities and desire or interest - to the possibility that we can't always get what we want, even in the cognitive realm. [...] I will therefore interpret realism ${ }_{m}$ as the thesis that truth is completely independent of our cognitive constitution (completely independent both of our capacites and interest, as far as we can tell from our concept of truth), and anti-realism $\mathrm{m}$ as denial of this thesis." Maudemarie Clark, Nietzsche on Truth and Philosophy (Cambridge: Cambridge University Press, 1990) 51.

11 Ibid., 22.

12 "Because he treats logic and mathematics as formal sciences that make no claims about reality, Nietzsche must surely abandon his earlier claim that they falsify reality. He also rejects as 'miscarriage' doctrines which can get off ground only on the assumption (shared by Plato, Descartes, Schopenhauer, and early Nietzsche, among others) that the sense deceive us, that they tell us only about 'appearance,' and not reality. [...] These passages from TI and A contain no hint of the view that human truths, science, logic, mathematics, or causality falsify reality. Instead, they exhibit a uniform and unambiguous respect for facts, the senses, and science. [...] Nietzsche does not claim that knowledge falsifies in his last six works." Ibid., 105.

13 "Nietzsche' last six books therefore provide no evidence of his commitment to the falsification thesis, no reason to deny his commitment to the possibility of truth in 
science, nor to the truth of his own theories. Given his earlier works, this seems remarkable and in need of explanation. I find the most plausible explanation to be that Nietzsche abandoned the falsification thesis because he realized that his account of the thing-in-itself as a contradiction in terms deprived him of any basis for it. [...] [1] took Nietzsche some time to realize that his denial of truth depended on the assumption of a thing-in-itself." Cetak tebal dan kurung siku oleh saya. Ibid., $108-9$

14 Ibid., 135.

15 Bornedal menunjukkan bahwa Nietzsche melanjutkan posisi awalnya seperti yang tertulis dalam Naclaß: "Man seeks 'truth': a world that does not contradict itself, does not deceive, does not change; a true world-a world in which man does not suffer: from contradiction, deception, change - the origins of suffering! Man does not doubt that such a world, as it should be, exists. [Consequently], he has to purse the path that leads to it. [...] The conviction that the world, as it should be, is, really exists, is the conviction of the unproductive, who does not want to create the world as it should be. He assumes it is present, and searches for the means and manners by which to reach it. - The Will to Truth'- as the powerlesness of the will to creation." Bornedal, op. cit., 108. Juga dari materi Nachlaß terakhir kita membaca: "Adalah kepentingan yang utama bahwa kita mengabaikan dunia sejati. Ia adalah sang peragu dan pengurang nilai ulung akan dunia kita sekarang: Sejauh ini ia adalah suatu upaya pembunuban terhadap kehidupan." Ibid., 108.

16 "When we therefore read Nietzsche's Analytic commentators excusing, amending, or mitigating Nietzsche's 'falsification' or 'error-theory,' they are committing a mistake so essential, that if by any chance they were right about Nietzsche being wrong, they would have annihilated their own cognitive and linguistic capabilities. Nietzsche's 'error' is the condition of the possibility for the reasoning of Analytic commentators (for example, the many 'I shall argue that ...' are falsifications of a text that is both much more than, and often much different from, the proposed 'argument'). One 'forgets,' that Nietzsche 'false' is not identical to Tarki's 'false'; his 'Truth' not identical to Tarski's 'true."' Ibid., 134.

17 "To begin with, a nerve stimulus is transferred into an image: first metaphor. The image, in turn, is imitated in a sound: second metaphor. And each time there is a complete overleaping of one sphere, right into the middle of an entirely new and different one.” Breazeale, op. cit., 82 [KSA 1, 879]—cetak tebal dan kurung siku oleh saya.

18 Saya menerjemahkan kata kerja “übertragen" (Jerman) sebagai “mengalihkan". Breazeale menyatakan bahwa kata kerja tersebut diturunkan dari kata kerja Yunani, $\mu \varepsilon \tau a \phi \varepsilon \dot{\varrho} \omega$, yang dapat berarti "membawa", "mengirim", "menerjemahkan", atau "mengalihkan". Ibid., 41. Kendati demikian, ragam konotasi makna tersebut menegaskan aktivitas perpindahan sesuatu dari ranah yang satu ke ranah yang lain.

19 "What is a word? It is the copy in sound of a nerve stimulus. But the further inference from the nerve stimulus to a cause outside of us is already the result of a a false and unjustifiable application of the principle of sufficient reason. If truth alone had been the deciding factor in the genesis of language, and if the standpoint of certainty had been decisive for designations, then how could we still dare to say 'the stone is hard,' as if 'hard' were something otherwise familiar to us, and not merely a totally subjective stimulation! We separate things according to gender, designating the tree as masculine and the plants as feminine. What arbirtrary assignments!' Ibid., 81-2 [KSA 1, 878] — cetak tebal dan kurung siku oleh saya.

20 Istilah "dipegang sebagai yang benar" bukanlah istilah khas Nietzsche. Namun, istilah tersebut sebelumnya telah digunakan oleh Kant. Martin Heidegger juga 
menggunakan istilah tersebut ketika menganalisis kritik Nietzsche terhadap dualisme realitas. Analisis Heidegger tersebut berjudul "Kebenaran dan Perbedaan antara 'Dunia Sejati dan Dunia Penampakan"'. Dalam paragraf pertama Hedegger menulis, "Hingga kini menjadi jelas bahwa kebenaran adalah apa yang dipegangsebagai-yang-benar [Für-wabr-halten], esensi dari dipegang-sebagai-yang-benar tersebut adalah intensi perspektif serta bercakrawala pandang dan antisipasi terhadap identitas dan kesamaan sebagai dasar permanensi [Beständigkeit]. Sebagai pembentuk cakrawala tetap dalam perspektif permanensi, pengetahuan juga membentuk esensi kehidupan manusia sejauh kehidupan manusia tersebut berhubungan dengan pengada-pengada. Karena pengetahuan juga membentuk kestabilan yang sangat penting bagi kehidupan manusia, pengetahuan merupakan suatu kondisi intrinsik dalam kehidupan. Nietzsche memahami kebenaran sebagai apa yang dipegangsebagai-yang-benar; yakni, ia memahami [kebenaran sebagai] mengambilnya-bagipengada [Für-seiend-nehmen] sebagai suatu keniscayaan nilai [einen notwendigen Wert], meskipun bukan sebagai suatu nilai tertinggi [wenngleich nicht als den höchsten]. Martin Heidegger, Nietzsche, Volume III, trans. Joan Stambaugh, David Farell Krell, and Frank A. Capuzzi (San Francisco: Harper \& Row Publisher, Inc., 1987) 123. Kurung siku dan cetak tebal oleh saya, didasarkan pada Martin Heidegger, Nietzsche: Erster Band (Frankfurt am Main: Vittorio Klostermann GmbH, 1996) 570.

21 Bornedal mencatat bahwa gagasan mengenai citra persepsi sebagai "tanda" diadopsi dari gagasan Helmhotz (Bornedal, op. cit., 60 catatan kaki no. 49). Dalam catatan kaki tersebut ia menyatakan, "In Erwin Schlimgen, we find the following account: 'Nietzsche's concept of image should here not be thought as a copy in relation to reality; it already replaces something (and has as such sign-character) which has no ontic status, of which it could not be a copy.' Schlimgen: Nietssche Theorie des Bewnßtseins. Berlin/New York (Walter de Gruyter), 1998, p. 73. In Christian Emden we read: 'The transition from perception to language accordingly proceeds in a "metaphorical" manner [. . .] and does not start with any kind of external reality or some pseudo-Kantian thing-in-itself.' Emden: Nietzsche on Rhetoric and Neuropsychology, loc. cit., p. 101. The two comentators may be right in saying that Nietzsche's interpretation-processes do not start in any 'ontic' or 'external' reality, since these processes are meant to explain the constitution of exactly such an onticexternal reality, but they do start in something, namely in the nerve-stimulus, which to this author's mind is a perfect candidate for a 'pseudo-Kantian' thing-in-itself."

22 "Metaphor, therefore, is determined by philosophy as a provisional loss of meaning, an economy of the proper without irreparable damage, a certainly inevitable detour, but also a history with its sights set on, and within the horizon of, the circular reappropriation of literal, proper meaning. This is why the philosophical evaluation of metaphor always has been ambiguous: metaphor is dangerous and foreign as concerns intuition (vision or contact), concept (the grasping or proper presence of the signified), and consciousness (proximity or self-presence); but it is in complicity with what it endangers, is necessary to it in the extent to which the de-tour is a return guided by the function of resemblance (mimêsis or homoiôsis), under the law of the same. [...] Metaphor, then, always carries its death within itself. And this death, surely, is also the death of philosophy." Jacques Derrida, "White Mythology", In Margins of Philosophy, trans. Alan Bass (Sussex: The Harvester Press, 1982) 270-1.

23 Ruediger H. Grimm merupakan salah seorang penafsir yang menyatakan bahwa Nietzsche menolak pembakuan kebenaran. Dalam Nietzsche's Theory of Knowledge (Berlin: Walter de Gruyter, 1977) 27, Grimm menulis, "What Nietzsche means when he says '... es giebt keine "Wahrheit"' is this: there is no ultimate, immutable, eternal standard for truth. The quanta of the will to power (i.e. 'reality') are constantly shifting, realigning themselves, overcoming or being overcome. A never-changing 
standard of truth simply does not apply, for it presupposes a totally inadequate understanding of being. Reality is constantly changing, constantly in flux, and a concept of truth which remains ignorant of this is simply irrelevant."

24 "This sheds light on our own notion of living metaphor. Metaphor is living not only to the extent that it vivifies [menghidupkan] a constituted language. Metaphor is living by virtue of the fact that it introduces the spark of imagination into a 'thinking more' at the conceptual level. This struggle to 'think more,' guided by the 'vivifying principle,' is the 'soul' of interpretation.” Paul Ricoeur, Rule of Metaphor, trans. Robert Czerny, Kathleen McLaughlin, and John Costello (London and New York: Routledge, 2003) 358.

25 "An aphorism, properly stamped and molded, has not been 'deciphered' when it has simply been read; rather, one has then to begin its exegesis, for which is required an art of exegesis. [...] To be sure, one thing is necessary above all if one is to practice reading as an art in this way, something that has been unlearned most thoroughly nowadays - and therefore it will be some time before my writings are 'readable' something for which one has almost to be a cow and in any case not a 'modern man': rumination.” Kaufmann, op. cit., 459. Cetak tebal dan kurung siku oleh saya.

26 Projek Nietzsche untuk mengingatkan kembali unsur simbolis dan figuratif dalam bahasa dipengaruhi oleh filsuf Jerman, Friedrich Albert Lange (1828-1875). Claudia Crawford dalam The Beginnings of Nietssche's Theory of Language (Berlin: Walter de Gruyter, 1988), 85 menyatakan, "Although language does not represent truth it is still a basic necessity in the preservation of the species and as such we are constrained to operate within its restraints. In his [Lange] insistence that language and philosophy, even science, are ultimately useful imagery, poetic expression, which prompts toward the ideal, Lange opens the possibility of a figurative use of language which had a great influence upon Nietzsche."

27 Reg Hollingdale menyatakan bahwa Nietzsche adalah seorang yang sangat serius, detail, dan hati-hati dalam merancang bukunya. Dalam Kata Pengantar akan teks Nietzsche $G D$ dan $A$ edisi bahasa Inggris (London: Penguin Books) Hollingdale menyatakan, "Nietzsche, it should be remarked, was very fond of composing plans for books: his posthumous papers include dozens of such plans, among them twenty-five different plans for the projected but unrealized Will to Power and several for books which exists only as plans; he also drew an number of title pages for ghostly books, with title, author and publisher neatly inked in and only the date of publication omitted." R.J. Hollingdale, "Introduction", In Twilight of the Idols and Antichrist (London: Penguin Books, 1968) 15.

28 Potongan teks tersebut menyatakan, "Supposing truth is a woman-what then? Are there not grounds for the suspicion that all philosophers, insofar as they were dogmatists, have been very inexpert about women? That the gruesome seriousness, the clumsy obstrusiveness with which they have usually approached truth so far have been awkward and very improper methods for winning a woman's heart? What is certain is that she has not allowed herself to be won-and today every kind of dogmatism is left standing dispirited and discouraged. If it is left standing at all! For there are scoffers who claim that it has fallen that all dogmatism lies on the ground-even more, that all dogmatism is dying." Friedrich Nietzsche, Beyond Good and Evil, trans. Walter Kaufmann (New York: Vintage Books, 1966) 2. Salah satu analisis mendalam mengenai kebenaran sebagai perempuan diuraikan oleh A. Setyo Wibowo dalam buku Gaya Filsafat Nietzsche (Yogyakarta: Galang Press, 2004) 123-52. Setyo menganalisis dan memberi catatan-catatan kritis terhadap berbagai pengertian kebenaran Nietzschean yang ditafsirkan oleh St. Sunardi, Goenawan Mohamad, dan Jacques Derrida. 